\title{
MANAGEMENT PROCESSES IN A PUBLIC ORGANIZATION PROVIDING SERVICES TO CITIZENS
}

\author{
ȚÎȚU Aurel Mihail ${ }^{1}$ and OLTEANU Constantin-Dorin ${ }^{2,3}$ \\ ${ }^{1}$ Lucian Blaga University of Sibiu, 10 Victoriei Street, Sibiu, România, mihail.titu@ulbsibiu.ro \\ ${ }^{2}$ Polytechnic University of Bucharest, Faculty of Industrial Engineering and Robotics \\ ${ }^{3}$ Directorate for the Registration of Persons, 14 Câmpului Street, Sibiu, Romania, ocosti@gmail.com
}

\begin{abstract}
The scientific paper proposes a pragmatic perspective of presenting some theoretical and practical aspects regarding a new approach within the studied organization, a process-based approach. The point of view submitted is a small part of the possibilities to implement the process-based approach. For an overview, I did a presentation of the organization in which I carry out my activity, the Sibiu County Directorate for the Registration of Persons, I showed the place and the role of the organization. Later, I explained the way, was organized and the activities that take place in the organization. An important aspect was the realization, in the organization, of personal analysis to make a new, process-based approach. Based on these processes we have made a current map of processes. A further direction of research is building a new process map following analysis to improve the processes within the studied public organization. Subsequently, we intend to execute the modeling of processes with a method that we will establish later.
\end{abstract}

KEY WORDS: organization, management, process, process map

\section{INTRODUCTION}

It is notorious that public administration is one step behind private organizations in implementing and operating a quality management system. A quality management system can be an important tool for increasing quality by complying with the standardized standards ISO 9000: 2015.

The managerial evolutions in the public administration, done with small steps, and the resistance to change is high.

Public organizations need to change and function better. These appear in the context of the evolution of society, of alignment with the international context, and of the need to work efficiently.

ISO 9001:2015 is an international standard that defines the requirements for a quality management system. ISO 9001 is the most popular international standard, according to statistics published by the International Organization for Standardization (ISO). The current version of ISO 9001 is the one published in 2015. ISO 9001: 2015 can be implemented and certified in any organization, regardless of size, activity, form of ownership, or structure.

The ISO 9001: 2015 standard offers the requirements of the quality management system to maintain and develop the quality of the services and products offered. By implementing the ISO 9001: 2015 standard, the costs are reduced the management system within the company is improved/streamlined, and the quality of services is increased.

\section{PLACE AND ROLE OF THE COUNTY DIRECTORATE FOR THE REGISTRATION OF PERSONS SIBIU}

It is appreciated in the literature that administration can be defined as the activity of a group working together to achieve common goals. [5]

According to the law, the public administration in the administrative-territorial units is organized and operates based on the principles of decentralization, local autonomy, deconcentration of public services, eligibility of local public administration authorities, legality, and consultation of citizens in solving local problems of special interest. We note that local autonomy means the right and effective capacity of local public administration authorities to solve and manage, in the name and in the interest of the local authorities they represent, public affairs, under the law [9]. This right is exercised by the local and mayoral councils, as well as by the county councils, local public administration authorities elected by a universal, equal, direct, secret, and free vote.

The Sibiu County Directorate for the Evidence of Persons, (referred to as D.J.E.P. Sibiu) is organized under the Sibiu County Council and is a public institution of county interest, with legal personality, established by reorganizing the Civil Status Service of the specialized apparatus of the Sibiu County Council and the Population Registration Office within the Computerized Persons Registration Service of Sibiu County, under art. 6 of O.G. no. 84/2001 [11] on the establishment, organization and operation of community public services for the registration of persons, with subsequent amendments and completions, approved by Law no. 372/2002 [12], as well as under Decision no. 9/2005 of the Sibiu County Council.[13]

D.J.E.P. Sibiu coordinates and methodologically controls the activity of the local community public services for the registration of persons, in the administrative-territorial units where they are constituted, as well as of the civil status officers within the town halls of the administrative-territorial units in which they do not operate local public records services.

The activity of the institution is coordinated by the President of the Sibiu County Council, who may delegate, by order, the attributions conferred by law and other normative acts, to the vice-presidents, heads of functional departments, or staff of the specialized apparatus. Also, the coordination and methodological control of the institution is ensured, in a unitary way, by the Directorate for the Registration of Persons and Database Administration (hereinafter referred to as DEPABD), according to the legal provisions [8].

The activity of the D.J.E.P. Sibiu is carried out in the interest of the citizens and the community, in support of the state 
institutions, exclusively on the basis and in the execution of the law.

The purpose of the Sibiu County Directorate for the Registration of Persons is to exercise the powers conferred on it by law to implement the provisions of normative acts governing the activity of registration of persons, marital status, and issuance of identity documents, in the system of a one-stop-shop. The activity of the D.J.E.P. Sibiu is carried out in the interest of the person and the community, in the support of the state institutions, exclusively on the basis and in the execution of the law.

The main purpose of D.J.E.P. Sibiu is the coordination and methodological control of the activity of the local community public services for the registration of persons, constituted under the subordination of the local councils of the two municipalities - Sibiu and Mediaș, nine cities - Agnita, Avrig, Cisnădie, Copșa Mică, Dumbrăveni, Miercurea Sibiului , Ocna Sibiului, Săliște and Tălmaciu and of the communes - Dîrlos, Laslea, Orlat, Turnu Roșu, Slimnic, Șura Mică, Axente Sever and Șelimbăr, as well as the civil status officers from all the town halls in the county Sibiu.

The activity of the institution also considers the serving of natural and legal persons on the line of registration of persons and civil status. The legal basis of the institution's activity consists of normative acts in the field as well as working instructions, methodological norms, regulations, and provisions, under the strict coordination of the Directorate for Records and Database Administration, compliance with these provisions being a mandatory requirement for all employees. institution.

The activity of registering persons is methodologically coordinated at the national level by the Directorate for the Registration of Persons and Database Administration within the Ministry of Internal Affairs to ensure the unity of action of the administrative apparatus, respectively the unitary application of specific legal provisions. Legal support for the establishment of institutions with responsibilities in the field of personal records:

- Government Decision no. 1367/2009 [15];

- The Directorate for the Registration of Persons and the Administration of Databases is organized and operates, as a specialized body of the central public administration, with legal personality subordinated to the Ministry of Internal Affairs;

- Government Ordinance no. 84/2001 - the community public services for the registration of persons are organized, at the level of the local councils of communes, cities, and municipalities, as well as at the level of the county councils, respectively of the municipality of Bucharest. [2].

The concerns of the specialized institutions of the Romanian state for keeping records of persons and issuing identity documents appeared a long time ago. Initially, it was wanted to know the number of inhabitants, out of the need to know, as accurately as possible, the taxpayer population and the one to be mobilized for military purposes. Initially, this was possible through population censuses, later, to solve the numerous administrative, economic, social, and cultural problems, the need was felt to keep the nominal record of the persons.

\section{PRESENTATION OF THE COMPARTMENTS AND THEIR ROLE IN THE RESEARCH ORGANIZATION}

The Sibiu County Directorate for the Registration of Persons has an organizational structure consisting of two services and several compartments, being materialized through specific attributions, functional relations and management, coordination and control relations, as follows:

A. The civil status service within which two compartments operate:

- Coordination and control department, transcripts and name changes;

- Operations department mentions.

B. Persons records service;

C. Litigation, human resources, and public relations department;

D. IT department;

E. Financial accounting and the technical-material insurance department.

D.J.E.P. Sibiu is led by an executive director, appointed or dismissed by decision of the Sibiu County Council, with the approval of D.E.P.A.B.D., under the Methodology on the criteria for sizing the number of positions in the community public services of records, assets, and management human, financial and material resources, approved by $\mathrm{HG}$ no. $2104 / 2004$, with subsequent amendments and completions [7].

To achieve the established objectives, the activity of the institution is based on relations of authority (hierarchical, functional), cooperation, coordination, and control, according to the attributions established for each component structure.

The relations of hierarchical authority are established between the management of the institution and the structures subordinated to it to maintain, preserve and improve the state of functionality of the institution. The same type of relationship is established between the bosses and their subordinate staff.

Within the department where no management functions are provided, functional authority relations are established between the senior staff and the rest of the staff of these structures, to guide and combine in a unitary manner, under the proposed aims and objectives, their activity and tasks balancing, harmonizing the necessary efforts, and ensuring unity of action in achieving the objectives.

At the level of the institution, the control and coordination activity is the attribute of the management and is performed directly, or through the head of the service or department. Also, in the control activity, on specific lines of work, the management of the institution may engage other specialized personnel within the institution.

In applying the legal provisions, orders, instructions, or guidelines, as well as for the improvement of the activities falling within its sphere of competence, the executive director of the D.J.E.P. Sibiu has the right to issue dispositions according to legal norms. According to the law, the executive director is accountable to the President of the Sibiu County Council for the shortcomings found in the activity of D.J.E.P. Sibiu, as well as before the Sibiu County Council, for the entire activity it carries out, according to the attributions provided in the job description.

The executive director represents the institution in relations with the heads of the structures within the Sibiu County Council, within the Institution of the Prefect - Sibiu County, as well as with the commanders of the structures within the Ministry of Internal Affairs, or with institutions and bodies outside it, according to legal competences.

The organizational chart, the list of positions, and the number of staff are approved by decision of the Sibiu County Council, at the proposal of its President, after obtaining, in advance, the 
approval of the Directorate for Persons Records and Database Administration and the National Agency of Civil Servants.

The Sibiu County Directorate for the Registration of Persons has an organizational structure consisting of two services and several compartments, being concretized through specific attributions, functional relations, and management, coordination, and control relations. To achieve the established objectives, the activity of the institution is based on relations of authority (hierarchical, functional), cooperation, coordination, and control, according to the attributions established for each component structure.

\section{PRESENTATION OF PROCESSES WITHIN THE ORGANIZED ORGANIZATION IN THE CURRENT CONTEXT}

The process-based approach can be applied in any organization and any management system regardless of its type, size, or complexity, the process-based approach appears in ISO 9001: 2015 .

A process can be defined, according to ISO 9001: 2015, as "a set of interrelated or interacting activities, which transforms a set of input elements to achieve output elements that an internal or external client needs" [6]. Inputs and outputs can be tangible (equipment, materials, or components) or intangible (information or knowledge).

We can consider a process, a sequence of predefined activities, which by applying them achieve desired results, which combine the operations of the organization with the requirements of customers. In general, processes are cross-functional, horizontally, attached to the vertical hierarchical structure of the organization, and not a single person is responsible for the entire process [3].

Risk-based thinking, PDCA, and the process-based approach are three concepts that together form part of the ISO 9001: 2015 standard.

For each process, customers and other stakeholders can be defined (who can be internal or external to the organization), who are affected by the process and who define the desired outputs according to their needs and expectations. In other words, a process is an activity that transforms an input element into an output element, a set of interrelated or interacting activities that transforms inputs into outputs, and these activities need to be allocated resources.

All processes must be correlated with the objectives of the organization and must be designed to add value, depending on the field of activity and the complexity of the organization.

The process-based approach involves establishing the organization's processes to operate as an integrated and complete system in which the management system integrates processes and measures to meet objectives and processes define interdependent activities and verifications to provide the desired outputs.

Within the Sibiu County Directorate for the Registration of Persons, there is a regulation of organization and functioning in which the activities that take place within the organization are highlighted. Starting from this, one can identify the existing processes in the organization. [1]

\section{A.0 General Administration Process}

This process comprises a number of sub-processes, some of which are set out in Table 1:
Table 1. Sub-processes included in the General Administration Process

\begin{tabular}{|c|c|}
\hline A.0 & General Administration Process \\
\hline A. 1 & $\begin{array}{l}\text { The sub-process of coordinating the entire activity of } \\
\text { the D.J.E.P. Sibiu; }\end{array}$ \\
\hline A. 2 & $\begin{array}{l}\text { The sub-process of coordination and methodological } \\
\text { control of the activity of the local community public } \\
\text { services for the registration of persons and of the civil } \\
\text { status structures within Sibiu county; }\end{array}$ \\
\hline A. 3 & $\begin{array}{l}\text { Sub-process for managing the entire assets of the } \\
\text { institution; }\end{array}$ \\
\hline A. 4 & Sub-Process Budget substantiation D.J.E.P. Sibiu; \\
\hline A.5 & $\begin{array}{l}\text { Sub-process of appointment, sanction, suspension, } \\
\text { modification and termination of employment or, as the } \\
\text { case may be, employment, in accordance with the law, } \\
\text { for the staff of the D.J.E.P. Sibiu; }\end{array}$ \\
\hline A. 6 & $\begin{array}{l}\text { Sub-process for the application of the regulations in } \\
\text { force and the provisions regarding the activity of } \\
\text { improving the professional training of the staff; }\end{array}$ \\
\hline A. 7 & $\begin{array}{l}\text { Sub-process for preparing the annual activity report of } \\
\text { the D.J.E.P. Sibiu; }\end{array}$ \\
\hline A. 8 & $\begin{array}{l}\text { The sub-process of assigning tasks and/or } \\
\text { compartments to tasks and monitoring their } \\
\text { completion on time; }\end{array}$ \\
\hline A9. & $\begin{array}{l}\text { The sub-process of coordination of the activity on the } \\
\text { line of civil status and evidence of the persons at the } \\
\text { level of the specialized structures, periodically } \\
\text { analyzing the way of fulfilling the entrusted tasks; }\end{array}$ \\
\hline A10. & $\begin{array}{l}\text { The sub-process of offering support, guidance, and } \\
\text { control activities to the specialized territorial services; }\end{array}$ \\
\hline A. 11 & $\begin{array}{l}\text { Sub-process for the formulation of proposals for the } \\
\text { improvement of work, completion, and modification of } \\
\text { working methodologies, extension or restriction of } \\
\text { certain areas of activity, based on the conclusions } \\
\text { resulting from the activity of community public } \\
\text { services for the registration of persons and civil status } \\
\text { officers within county halls; }\end{array}$ \\
\hline A. 12 & $\begin{array}{l}\text { Sub-process for drawing up the establishment plan, list } \\
\text { of duties, rules of organization and operation; }\end{array}$ \\
\hline A. 13 & $\begin{array}{l}\text { Sub-process for approving and complying with the } \\
\text { Internal Regulations, the rules on occupational safety } \\
\text { and security and those on emergencies; }\end{array}$ \\
\hline A. 14 & $\begin{array}{l}\text { Sub-process for ensuring the protection of personal } \\
\text { data, as well as the security of the institution's } \\
\text { documents, under the legal provisions in force; }\end{array}$ \\
\hline A. 15 & Hearing Sub-Process. \\
\hline
\end{tabular}




\section{B.0 The Executive Management Process}

This process comprises many sub-processes, some of which are set out in Table 2:

Table 2. Sub-processes included in The Executive Management Process

\begin{tabular}{|c|c|}
\hline B.0 & Executive Management Process \\
\hline B.1 & $\begin{array}{l}\text { The sub-process of coordinating the activity of the } \\
\text { following compartments within the D.J.E.P. Sibiu: } \\
\text { - Litigation department, human resources, and public } \\
\text { relations; } \\
\text { - IT department; } \\
\text { - Financial-accounting and the technical-material } \\
\text { insurance department. }\end{array}$ \\
\hline B.2 & $\begin{array}{l}\text { The sub-process of organizing, guiding, and } \\
\text { coordinating the activity of elaborating the project of } \\
\text { the own budget of the D.J.E.P. Sibiu for the next year } \\
\text { and estimates for the next three years; }\end{array}$ \\
\hline B.3 & $\begin{array}{l}\text { The sub-process of organization and functioning in } \\
\text { good conditions of the accounting of the patrimonial } \\
\text { values; }\end{array}$ \\
\hline B.4 & $\begin{array}{l}\text { Sub-process for drawing up the accounting report, the } \\
\text { balance sheet, and its annexes; }\end{array}$ \\
\hline B.5 & $\begin{array}{l}\text { Sub-process for coordinating and monitoring the use of } \\
\text { funds approved by the budget together with the } \\
\text { specialized department; }\end{array}$ \\
\hline B.6 & $\begin{array}{l}\text { Sub-process for providing specialized assistance to } \\
\text { local community public services for the registration of } \\
\text { persons in Sibiu County; }\end{array}$ \\
\hline B.7 & $\begin{array}{l}\text { The sub-process of ensuring and organizing the activity } \\
\text { of the compartments and on each subordinate position, } \\
\text { based on an activity program; }\end{array}$ \\
\hline B. 8 & $\begin{array}{l}\text { The sub-process for tracking the preparation of staff } \\
\text { job descriptions, ensures their approval, completion, or } \\
\text { modification; }\end{array}$ \\
\hline B.9 & $\begin{array}{l}\text { The sub-process of organizing and exercising its } \\
\text { preventive financial control over the operations } \\
\text { projects, under the legal provisions; }\end{array}$ \\
\hline B. 10 & Hearing Sub-Process; \\
\hline B. 11 & $\begin{array}{l}\text { Sub-process for ensuring and complying with the } \\
\text { Internal Regulations, the rules on occupational safety } \\
\text { and security and those on emergencies; }\end{array}$ \\
\hline
\end{tabular}

\section{C.0 Civil Status Process}

This process comprises some sub-processes, some of which are set out in Table 3:
Table 3. Sub-processes included in Civil Status Process

\begin{tabular}{|c|c|}
\hline C.0 & Civil Status Process \\
\hline C.1 & $\begin{array}{l}\text { Sub-process of civil status administration by the head } \\
\text { of the civil status service. }\end{array}$ \\
\hline C.1.1 & $\begin{array}{l}\text { Sub-process of control, specialized counseling, } \\
\text { coordination, and training; }\end{array}$ \\
\hline C.1.2 & $\begin{array}{l}\text { The planning subprocess of the activities of } \\
\text { coordination and methodological control at the } \\
\text { specialized structures at the county level; }\end{array}$ \\
\hline C.1.3 & $\begin{array}{l}\text { The training sub-process of the new specialized } \\
\text { personnel employed in the field of civil status; }\end{array}$ \\
\hline C.1.4 & $\begin{array}{l}\text { The processing subprocess with the service } \\
\text { personnel, of the provisions of the current norms, for } \\
\text { their proper acquisition; }\end{array}$ \\
\hline C.1.5 & $\begin{array}{l}\text { The sub-process of specialized counseling, at the } \\
\text { notifications of the local community public services } \\
\text { for the registration of persons and the civil status } \\
\text { structures within the town halls in the county; }\end{array}$ \\
\hline C.1.6 & $\begin{array}{l}\text { Sub-process for verifying reports prepared by civil } \\
\text { servants within the Coordination, Control, } \\
\text { Transcription and Name Change Department; }\end{array}$ \\
\hline C.1.7 & $\begin{array}{l}\text { Sub-process of organizing training sessions for civil } \\
\text { status officers to improve their professional training; }\end{array}$ \\
\hline C.1.8 & $\begin{array}{l}\text { Sub-process for finding contraventions in the civil } \\
\text { status regime; }\end{array}$ \\
\hline C.1.9 & $\begin{array}{l}\text { Sub-process for the development of practical } \\
\text { guidelines (guidelines) for the correct application of } \\
\text { civil status legislation; }\end{array}$ \\
\hline C. 1.10 & $\begin{array}{l}\text { Sub-process for resolving, together with the } \\
\text { responsible person, the petitions of natural and legal } \\
\text { persons within the sphere of competence of the } \\
\text { service; }\end{array}$ \\
\hline C.1.11 & $\begin{array}{l}\text { The sub-process of permanent knowledge of the } \\
\text { normative acts in the matter of civil status; }\end{array}$ \\
\hline C. 1.12 & $\begin{array}{l}\text { Sub-process of information during meetings, } \\
\text { seminars, conferences, etc. in the field of civil status; }\end{array}$ \\
\hline C.1.13 & $\begin{array}{l}\text { The collaboration sub-process with the other } \\
\text { structures within the D.J.E.P. Sibiu and other public } \\
\text { authorities in the specific field of civil status; }\end{array}$ \\
\hline C. 1.14 & $\begin{array}{l}\text { Sub-process for granting hearings based on the } \\
\text { approved program. }\end{array}$ \\
\hline C. 2 & Control Coordination Subprocess \\
\hline C.2.1 & $\begin{array}{l}\text { The sub-process of guidance and control of the civil } \\
\text { status activity on the territory of the county; }\end{array}$ \\
\hline C.2.2 & $\begin{array}{l}\text { Sub-process for carrying out reports on the } \\
\text { conclusions of the verifications carried out in the case }\end{array}$ \\
\hline
\end{tabular}




\begin{tabular}{|c|c|}
\hline & $\begin{array}{l}\text { of applications and other documents for the renaming } \\
\text { of the administrative route; }\end{array}$ \\
\hline C. 2.3 & $\begin{array}{l}\text { Sub-process of a proposal for approval reports on } \\
\text { rectifications of civil status documents and entries in } \\
\text { them; }\end{array}$ \\
\hline C. 2.4 & $\begin{array}{l}\text { The sub-process for verifying the documentation } \\
\text { aimed at late registration of the birth and proposes to } \\
\text { give the assent; }\end{array}$ \\
\hline C. 2.5 & $\begin{array}{l}\text { Subprocess to propose for approval the reports on the } \\
\text { reconstitution and subsequent preparation of civil } \\
\text { status documents; }\end{array}$ \\
\hline C. 2.6 & $\begin{array}{l}\text { The sub-process for the employment of specialized } \\
\text { personnel in the field of civil status from the local } \\
\text { community public services for the registration of } \\
\text { persons and from the town halls in the county and } \\
\text { ensures the training of persons to whom the exercise } \\
\text { of civil status duties is to be delegated; }\end{array}$ \\
\hline С. 2.7 & $\begin{array}{l}\text { The sub-process of specialized counseling to solve } \\
\text { some cases in the field of civil status, notified by the } \\
\text { local community public services for the registration } \\
\text { of persons and the civil status structures within the } \\
\text { town halls in the county; }\end{array}$ \\
\hline C. 2.8 & $\begin{array}{l}\text { The sub-process of centralization and elaboration of } \\
\text { monthly, quarterly, and half-yearly statistical } \\
\text { statements regarding the civil status activity in the } \\
\text { county, as well as the one carried out by the Civil } \\
\text { Status Service within the D.J.E.P; }\end{array}$ \\
\hline C. 2.9 & $\begin{array}{l}\text { Sub-process for verifying the assignment, } \\
\text { management, and registration of pre-calculated } \\
\text { personal numerical codes in civil status documents; }\end{array}$ \\
\hline C. 2.10 & $\begin{array}{l}\text { Sub-process for finding contraventions in the civil } \\
\text { status regime; }\end{array}$ \\
\hline C.2.11 & $\begin{array}{l}\text { Subprocess of the proposal for the annulment or } \\
\text { completion of the civil status documents, copy II and } \\
\text { of the mentions inscribed on them, as the case may } \\
\text { be, according to the law following the notifications } \\
\text { of the courts; }\end{array}$ \\
\hline C. 2.12 & $\begin{array}{l}\text { Sub-process for training civil status officers to } \\
\text { improve their professional training; }\end{array}$ \\
\hline C. 2.13 & $\begin{array}{l}\text { The sub-process of permanent knowledge of the } \\
\text { normative acts in the matter of civil status; }\end{array}$ \\
\hline C. 2.14 & $\begin{array}{l}\text { The sub-process for resolving the assigned civil } \\
\text { status correspondence within the legal term; }\end{array}$ \\
\hline C. 2.15 & $\begin{array}{l}\text { Sub-process for following the way of solving the } \\
\text { deficiencies recorded in the control report for } \\
\text { correcting errors in the civil status documents; }\end{array}$ \\
\hline C.2.16 & $\begin{array}{l}\text { Sub-process for drawing up information, circulars, } \\
\text { guidelines for the correct application of the } \\
\text { legislation in the field of civil status which it } \\
\text { transmits to the local community public services for }\end{array}$ \\
\hline
\end{tabular}

\begin{tabular}{|c|c|}
\hline & $\begin{array}{l}\text { the registration of persons and civil status structures } \\
\text { within the county town halls; }\end{array}$ \\
\hline C. 2.17 & $\begin{array}{l}\text { The sub-process for resolving petitions on specific } \\
\text { issues, in collaboration with the person responsible } \\
\text { for the activity of resolving petitions, according to the } \\
\text { resolution of the executive director and aims to } \\
\text { resolve them within the legal deadline. }\end{array}$ \\
\hline C. 3 & $\begin{array}{l}\text { The sub-process, Entries Operation in the Civil } \\
\text { Status Registers }\end{array}$ \\
\hline C. 3.1 & $\begin{array}{l}\text { The sub-process for recording, preserving, and } \\
\text { ensuring the security of the civil status registers, copy } \\
\text { II, of the other documents in the civil status archive, } \\
\text { as well as of the stamps for mentions; }\end{array}$ \\
\hline C. 3.2 & $\begin{array}{l}\text { The subprocess of operation in the civil status } \\
\text { registers, copy II, within the legal terms, the } \\
\text { communications of mentions, returns the incomplete } \\
\text { or incorrectly completed mentions; }\end{array}$ \\
\hline C. 3.3 & $\begin{array}{l}\text { Sub-process for issuing extracts from birth, marriage, } \\
\text { and death certificates at the request of public } \\
\text { authorities provided by Law no. } 119 / 1996 \text {; }\end{array}$ \\
\hline C. 3.4 & $\begin{array}{l}\text { Sub-process for reconstitution by copying, of the } \\
\text { civil status, registers lost or destroyed, partially or, } \\
\text { according to the existing copy, certifying the } \\
\text { accuracy of the entered data; }\end{array}$ \\
\hline C. 3.5 & $\begin{array}{l}\text { The sub-process of specialized counseling of the civil } \\
\text { status officers from the county regarding the mode of } \\
\text { operation, within the civil status documents, of the } \\
\text { changes that occurred in the civil status of the person; }\end{array}$ \\
\hline C. 3.6 & $\begin{array}{l}\text { The sub-process of permanent knowledge of the } \\
\text { normative acts in the matter of civil status; }\end{array}$ \\
\hline C. 3.7 & $\begin{array}{l}\text { The sub-process for resolving petitions on specific } \\
\text { issues, in collaboration with the person responsible } \\
\text { for the activity of resolving petitions, according to the } \\
\text { resolution of the executive director and aims to } \\
\text { resolve them within the legal deadline. }\end{array}$ \\
\hline
\end{tabular}

\section{D.0 General Records Process}

This process comprises some sub-processes, some of which are set out in Table 4:

Table 4. Sub-processes included in General Records Process

\begin{tabular}{|c|l|}
\hline D.0 & \multicolumn{1}{|c|}{ General Records Process } \\
\hline D.1 & $\begin{array}{l}\text { The sub-process for the administration of the person } \\
\text { record service by the head of the person record } \\
\text { service. }\end{array}$ \\
\hline D.1.1 & $\begin{array}{l}\text { The sub-process of ensuring the development of the } \\
\text { service activity in good conditions and of taking the } \\
\text { appropriate measures to make it more efficient; }\end{array}$ \\
\hline D.1.2 & $\begin{array}{l}\text { The sub-process of coordinating the activity on the } \\
\text { line of evidence of persons of the local community } \\
\text { public services of evidence of persons from Sibiu }\end{array}$ \\
\hline
\end{tabular}




\begin{tabular}{|c|c|}
\hline & $\begin{array}{l}\text { County, to ensure a unitary way of solving citizens' } \\
\text { requests, in compliance with the legal norms in force; }\end{array}$ \\
\hline D.1.3 & $\begin{array}{l}\text { The sub-process for drawing up the quarterly activity } \\
\text { plans on the line of records of persons, presents them } \\
\text { to the executive director of the D.J.E.P. Sibiu to } \\
\text { approve and take the necessary measures to carry out } \\
\text { the tasks mentioned in them, within the established } \\
\text { deadlines; }\end{array}$ \\
\hline D.1.4 & $\begin{array}{l}\text { The sub-process of preparing the analyzes of the } \\
\text { evaluation the activities carried out according to the } \\
\text { tasks contained in the activity plans and presents } \\
\text { them to the executive director of the D.J.E.P. Sibiu, } \\
\text { for approval; }\end{array}$ \\
\hline D.1.5 & $\begin{array}{l}\text { The sub-process of organizing the meetings of } \\
\text { periodic analysis of the specific activity on the line } \\
\text { of evidence of the persons, establishing the way of } \\
\text { accomplishing the specific attributions; }\end{array}$ \\
\hline D.1.6 & $\begin{array}{l}\text { The processing subprocess with the service } \\
\text { personnel, the provisions of the line legal norms, to } \\
\text { acquire and apply exactly, in a unitary way, their } \\
\text { dispositions; }\end{array}$ \\
\hline D.1.7 & $\begin{array}{l}\text { The sub-process of receiving the works specific to } \\
\text { the records of the persons distributed by the } \\
\text { executive director of the D.J.E.P. Sibiu and } \\
\text { distributes them to specialized officials for } \\
\text { settlement, in compliance with legal provisions in the } \\
\text { field; }\end{array}$ \\
\hline D.1.8 & $\begin{array}{l}\text { The sub-process for verifying the module and the } \\
\text { term for solving the works prepared by the service } \\
\text { officials; }\end{array}$ \\
\hline D.1.9 & $\begin{array}{l}\text { The sub-process for solving the works assigned by } \\
\text { the executive director of the D.J.E.P. Sibiu; }\end{array}$ \\
\hline D.1.10 & $\begin{array}{l}\text { Sub-process of taking the necessary measures to } \\
\text { resolve the petitions registered at the level of the } \\
\text { directorate, in the field of personal records; }\end{array}$ \\
\hline D.1.11 & $\begin{array}{l}\text { Sub-process of taking appropriate measures to draw } \\
\text { up the daily planning of staff carrying out specific } \\
\text { activities to issue the identity document or enter in } \\
\text { the identity document the statement on the } \\
\text { establishment of residence; }\end{array}$ \\
\hline D.1.12 & $\begin{array}{l}\text { The sub-process of organizing and participating in } \\
\text { the training activities of the officials of the } \\
\text { community public services for the registration of } \\
\text { persons from Sibiu County and testing the theoretical } \\
\text { and practical knowledge acquired by them in the } \\
\text { field of registration of persons, to grant the right to } \\
\text { update the computerized component National } \\
\text { Register of Persons; }\end{array}$ \\
\hline D.1.13 & $\begin{array}{l}\text { The sub-process of participating in the organization } \\
\text { of professional convocations on the line of evidence } \\
\text { of persons and on the occasion of their development, } \\
\text { provides the staff of the S.P.C.L.E.P. from Sibiu } \\
\text { county the necessary guidance; }\end{array}$ \\
\hline
\end{tabular}

\begin{tabular}{|l|l|}
\hline D.1.14 & $\begin{array}{l}\text { The sub-process for drawing up at the beginning of } \\
\text { each year, for the current year, the Graph regarding } \\
\text { the planning of methodological controls at the local } \\
\text { community public services for the registration of } \\
\text { persons within Sibiu county; }\end{array}$ \\
\hline D.1.15 & $\begin{array}{l}\text { The sub-process of organizing and conducting the } \\
\text { methodological control of the activity of solving the } \\
\text { applications for issuing the identity document, } \\
\text { respectively of the applications for entering in the } \\
\text { identity document the mention regarding the } \\
\text { establishment of residence, as well as the receipt of } \\
\text { applications and issuance of other documents, within } \\
\text { the one-stop-shop, by the local community public } \\
\text { services for the registration of persons from Sibiu } \\
\text { County, to ensure a unitary way of applying the legal } \\
\text { regulations incident inactivity; }\end{array}$ \\
\hline D.1.16 & $\begin{array}{l}\text { The sub-process of drawing up, together with the } \\
\text { members of the control commission, the control } \\
\text { report comprising the main achievements of the } \\
\text { controlled structure, the deficiencies and } \\
\text { irregularities found, the measures and deadlines for } \\
\text { their remedy, as well as the proposals that can } \\
\text { contribute to increasing the efficiency of the } \\
\text { controlled structure; }\end{array}$ \\
\hline D.1.21 \\
\hline D.1.20
\end{tabular}




\begin{tabular}{|c|c|}
\hline & $\begin{array}{l}\text { necessary for the activity of the service, according to } \\
\text { the legal provisions in force; }\end{array}$ \\
\hline D.1.24 & $\begin{array}{l}\text { Sub-process of taking appropriate measures to ensure } \\
\text { the protection of personal data and classified } \\
\text { information managed at the level of the service, in } \\
\text { accordance with the legal provisions in force; }\end{array}$ \\
\hline D.1.25 & $\begin{array}{l}\text { The sub-process of taking the necessary measures in } \\
\text { order to apply at the service level the legal provisions } \\
\text { that regulate the activity of registration of persons; }\end{array}$ \\
\hline D.1.26 & $\begin{array}{l}\text { Sub-process for formulating proposals for improving } \\
\text { the activity, completing and amending normative } \\
\text { acts and working methodologies in the field of } \\
\text { personal records; }\end{array}$ \\
\hline D.1.27 & $\begin{array}{l}\text { The sub-process of granting hearings on the basis of } \\
\text { the program approved, in this respect, by order of the } \\
\text { executive director of the D.J.E.P. Sibiu. }\end{array}$ \\
\hline$D .2$ & The sub-process registration of persons \\
\hline D.2.1 & $\begin{array}{l}\text { The sub-process of coordination and methodological } \\
\text { control of the activity of settling applications for the } \\
\text { issuance of the identity document, respectively of the } \\
\text { applications for registration in the identity document } \\
\text { of the statement on the establishment of residence, as } \\
\text { well as the receipt of applications and issuance of } \\
\text { other documents, within the one-stop-shop, by the } \\
\text { local community public services for the registration } \\
\text { of persons from Sibiu County, to ensure a unitary } \\
\text { way of applying the legal regulations incident to } \\
\text { these activities; }\end{array}$ \\
\hline D.2.2 & $\begin{array}{l}\text { The sub-process for drawing up at the beginning of } \\
\text { each year, for the current year, the Schedule } \\
\text { regarding the planning of methodological controls at } \\
\text { the local community public services for the } \\
\text { registration of persons from Sibiu County; }\end{array}$ \\
\hline D.2.3 & $\begin{array}{l}\text { Process carried out at the end of the established } \\
\text { methodological control activities, of preparation, } \\
\text { submission for approval to the executive } \\
\text { management of the D.J.E.P. Sibiu and transmission } \\
\text { to the controlled profile service, as well as to the } \\
\text { management of the local public authority concerned, } \\
\text { of the Control Report containing the main } \\
\text { achievements of the controlled structure, the } \\
\text { deficiencies and irregularities found, the measures } \\
\text { and deadlines for their remedy, as well as the } \\
\text { proposals. controlled structure; }\end{array}$ \\
\hline D.2.4 & $\begin{array}{l}\text { Sub-process of collaboration with the Executive } \\
\text { Director / Head / Coordinator of the local } \\
\text { Community Public Service for the registration of } \\
\text { persons to know directly the stage and manner of } \\
\text { carrying out the measures established during the } \\
\text { control activity, as well as other tasks and duties the } \\
\text { return; }\end{array}$ \\
\hline D.2.5 & $\begin{array}{l}\text { The sub-process of guiding the staff of the local } \\
\text { community public services for the registration of } \\
\text { persons, elaborating in this respect, as the case may } \\
\text { be, specific work norms; }\end{array}$ \\
\hline
\end{tabular}

\begin{tabular}{|c|c|}
\hline D.2.6 & $\begin{array}{l}\text { The sub-process for solving the requests for } \\
\text { specialized points of view formulated by the profile } \\
\text { services under the coordination of the D.J.E.P. Sibiu; }\end{array}$ \\
\hline D.2.7 & Sub-process for resolving petition records; \\
\hline D.2.8 & $\begin{array}{l}\text { The sub-process for solving the works on the line of } \\
\text { evidence of persons, assigned by the executive } \\
\text { director D.J.E.P. Sibiu, respectively the head of the } \\
\text { service, ensuring their quality and accuracy; }\end{array}$ \\
\hline D.2.9 & $\begin{array}{l}\text { The sub-process of receiving, verifying, and } \\
\text { centralizing the information communicated by the } \\
\text { local community public services for the registration } \\
\text { of persons from Sibiu County regarding the activities } \\
\text { carried out for the legalization of citizens holding } \\
\text { identity documents whose validity period has } \\
\text { expired; }\end{array}$ \\
\hline D.2.10 & $\begin{array}{l}\text { Sub-process for solving requests for assigning the } \\
\text { personal numerical code, under the law; }\end{array}$ \\
\hline D.2.11 & $\begin{array}{l}\text { The sub-process of organizing professional } \\
\text { convocations on the line of evidence of persons and, } \\
\text { on the occasion of their conduct, provides the staff of } \\
\text { the S.P.C.L.E.P. from Sibiu county the necessary } \\
\text { instructions, according to the agenda approved by the } \\
\text { executive director of D.J.E.P. Sibiu; }\end{array}$ \\
\hline D.2.12 & $\begin{array}{l}\text { The sub-process for coordinating the specific } \\
\text { activities carried out by the S.P.C.E.P. from Sibiu } \\
\text { County to legalize the persons registered in the } \\
\text { protection and social protection units within the } \\
\text { competence, respectively to control the way of } \\
\text { observing the provisions of the legal norms on the } \\
\text { persons these units; }\end{array}$ \\
\hline D.2.13 & $\begin{array}{l}\text { The sub-process for establishing the measures } \\
\text { necessary for the preservation and operation of } \\
\text { manual records, held by the local community public } \\
\text { services for the registration of persons, under the } \\
\text { legal provisions, orders, and instructions governing } \\
\text { this field of activity; }\end{array}$ \\
\hline D.2.14 & $\begin{array}{l}\text { Sub-process of receiving applications for the } \\
\text { issuance of the identity document and applications } \\
\text { for registration in the identity document of the } \\
\text { statement on the establishment of residence, as well } \\
\text { as the documents submitted in support of them, in the } \\
\text { case of citizens who obtained the approval of } \\
\text { D.J.E.P. Sibiu for solving specific requests at the } \\
\text { level of this institution, being in special situations, or } \\
\text { in case of testing applications or following the } \\
\text { operation of the equipment; }\end{array}$ \\
\hline D.2.15 & $\begin{array}{l}\text { Sub-process for taking over the images of the } \\
\text { applicants for the identity document and, as the case } \\
\text { may be, of the persons requesting the registration in } \\
\text { the identity document of the mention regarding the } \\
\text { establishment of the residence; }\end{array}$ \\
\hline D.2.16 & $\begin{array}{l}\text { Sub-process of carrying out the necessary activities } \\
\text { to resolve, according to the legal norms of the line, } \\
\text { the applications for issuing the identity document and } \\
\text { the applications for registration in the identity }\end{array}$ \\
\hline
\end{tabular}




\begin{tabular}{|c|c|}
\hline & $\begin{array}{l}\text { document of the mention regarding the establishment } \\
\text { of residence, according to the planning recorded in } \\
\text { the specific register; }\end{array}$ \\
\hline \multirow[t]{2}{*}{ D.2.17 } & $\begin{array}{l}\text { Sub-process of carrying out appropriate activities to } \\
\text { ensure the flow of data and information necessary to } \\
\text { perform specific tasks in the field of personal } \\
\text { records; }\end{array}$ \\
\hline & $\begin{array}{l}\text { The sub-process of carrying out activities necessary } \\
\text { for the maintenance of the endowment calculation } \\
\text { technique; }\end{array}$ \\
\hline D.2.19 & $\begin{array}{l}\text { The sub-process of drawing up, using, and keeping } \\
\text { the records necessary for carrying out the activity, } \\
\text { according to the legal provisions in force; }\end{array}$ \\
\hline D.2.20 & $\begin{array}{l}\text { The sub-process of bringing to the citizens' notice the } \\
\text { necessary information to legalize the persons, } \\
\text { according to the legal norms; }\end{array}$ \\
\hline D.2.21 & $\begin{array}{l}\text { Sub-process for cancellation of withdrawn identity } \\
\text { documents, as a result of requesting the issuance of } \\
\text { new identity documents; }\end{array}$ \\
\hline D.2.22 & $\begin{array}{l}\text { The sub-process of providing specialized support to } \\
\text { local public authorities on the occasion of the } \\
\text { establishment and operationalization of new } \\
\text { S.P.C.L.E.P. at the level of Sibiu county; }\end{array}$ \\
\hline D. 2.23 & $\begin{array}{l}\text { The subprocess of organizing and carrying out } \\
\text { training activities for community public service } \\
\text { officials for the registration of persons in Sibiu } \\
\text { County and testing the theoretical and practical } \\
\text { knowledge acquired by them in the field of personal } \\
\text { records, to grant the right to update the computerized } \\
\text { component of R.N.E. }\end{array}$ \\
\hline D.2.24 & $\begin{array}{l}\text { Subprocess of finding contraventions and application } \\
\text { of contraventional sanctions, under the law; }\end{array}$ \\
\hline D.2.25 & $\begin{array}{l}\text { The subprocess of ensuring the protection of personal } \\
\text { data and classified information, as well as the } \\
\text { security of service documents, under the legal } \\
\text { provisions in force; }\end{array}$ \\
\hline D.2.26 & $\begin{array}{l}\text { The sub-process of applying exactly the legal } \\
\text { provisions that regulate the activity of registration of } \\
\text { persons; }\end{array}$ \\
\hline D.2.27 & $\begin{array}{l}\text { Subprocess of formulation of proposals for the } \\
\text { improvement of the activity, completion, and } \\
\text { modification of the normative acts and the working } \\
\text { methodologies in the matter of the record of persons; }\end{array}$ \\
\hline D.2.28 & $\begin{array}{l}\text { The sub-process of ensuring the establishment of the } \\
\text { archival fund of the service, from the documents } \\
\text { resulted as a result of the development of the profile } \\
\text { activity. }\end{array}$ \\
\hline
\end{tabular}

\section{E.0 The Contentious-Legal Process}

This process comprises some sub-processes, some of which are set out in Table 5:
Table 5. Sub-processes included in the Contentious-Legal Process

\begin{tabular}{|c|c|}
\hline E.0 & Contentious-Legal Process \\
\hline E. 1 & $\begin{array}{l}\text { The sub-process of representation D.J.E.P. Sibiu, } \\
\text { before the courts, other jurisdictional bodies, criminal } \\
\text { prosecution bodies, notaries public and/or in relations } \\
\text { with other natural or legal persons, under the law, by } \\
\text { designation/delegation, power of attorney or express } \\
\text { mandate; }\end{array}$ \\
\hline \multirow[t]{5}{*}{ E. 2} & $\begin{array}{l}\text { The sub-process of ensuring the investigation of cases } \\
\text { pending before the courts, by: }\end{array}$ \\
\hline & $\begin{array}{l}\text { - drafting, signing, and submitting to the registry of the } \\
\text { courts, within the legal term, the procedural } \\
\text { documents, actions, objections, counterclaims, } \\
\text { clarifications, written conclusions, and the like, within } \\
\text { the legal terms, according to the procedural quality; }\end{array}$ \\
\hline & $\begin{array}{l}\text { - preparation and submission to the files, within the } \\
\text { legal term, of the evidentiary materials (documents, } \\
\text { expertises, etc.) and witnesses, as the case may be; }\end{array}$ \\
\hline & $\begin{array}{l}\text { - following up on court-ordered solutions and } \\
\text { promoting, where appropriate, appeals or drawing up } \\
\text { written reports, motivated by the decision to take such } \\
\text { decisions; }\end{array}$ \\
\hline & $\begin{array}{l}\text { - communication of court decisions to D.J.E.P. Sibiu, } \\
\text { to enforce them; }\end{array}$ \\
\hline E. 3 & $\begin{array}{l}\text { The sub-process of ensuring and following up the } \\
\text { evidence of the cases under trial, by recording, in a } \\
\text { special register, the files, the trial terms, as well as the } \\
\text { solutions given by the courts; }\end{array}$ \\
\hline E.4 & $\begin{array}{l}\text { Subprocess for providing specialized legal advice to } \\
\text { D.J.E.P. Sibiu, upon request, in compliance with the } \\
\text { relevant legal norms and principles, providing } \\
\text { information on the incidence of legal norms, applicable } \\
\text { to each situation, as well as their interpretation; study } \\
\text { in advance the issue before the attention, in the light of } \\
\text { the factual and legal elements pending the case; drafts } \\
\text { and provides, in writing, the reasoned opinion on the } \\
\text { matter referred to it; }\end{array}$ \\
\hline E. 5 & $\begin{array}{l}\text { The D.J.E.P. Sibiu to draw up draft administrative acts } \\
\text { and/or contracts, which it approves, from a legal point } \\
\text { of view, drafting in all cases written views on clauses } \\
\text { that do not comply with the law and/or inappropriate, } \\
\text { drawing up non-approval reports indicating the } \\
\text { inconsistency of the act approval with legal norms; }\end{array}$ \\
\hline E. 6 & $\begin{array}{l}\text { The sub-process of drawing up and centralizing the } \\
\text { contracts concluded by the management of the } \\
\text { institution; }\end{array}$ \\
\hline E.7 & $\begin{array}{l}\text { The subprocess of following the drafting of the } \\
\text { distributed documents regarding their substantiation, in } \\
\text { fact, and law; }\end{array}$ \\
\hline E. 8 & $\begin{array}{l}\text { Sub-process for providing information to citizens, } \\
\text { within the limits of the powers and attributions } \\
\text { conferred by the legal provisions in force; }\end{array}$ \\
\hline
\end{tabular}




\begin{tabular}{|l|l|}
\hline E.9 & $\begin{array}{l}\text { Sub-process for drafting legal documents, attestation } \\
\text { of the identity of the parties, consent, content, and date } \\
\text { of concluded documents; }\end{array}$ \\
\hline E.10 & $\begin{array}{l}\text { The sub-process for verifying the legality of legal and } \\
\text { administrative acts, which emanates from the } \\
\text { executive director of the D.J.E.P. Sibiu, which it } \\
\text { endorses and countersigns, as the case may be; }\end{array}$ \\
\hline E.11 & $\begin{array}{l}\text { The subprocess of elaboration of the specialized } \\
\text { reports underlying the issuance of orders of the } \\
\text { executive director of the D.J.E.P. Sibiu; }\end{array}$ \\
\hline E.12 & $\begin{array}{l}\text { Sub-process for endorsement, signing and initialing of } \\
\text { legal acts, positive or negative opinion, covering only } \\
\text { the strictly legal aspects of the respective document; }\end{array}$ \\
\hline E.13 & $\begin{array}{l}\text { Sub-process for approving supporting notes prepared } \\
\text { under the provisions of Law no. 98/2016 on public } \\
\text { procurement and H.G. no. 395/2016 for the approval of } \\
\text { the Methodological Norms for the application of the } \\
\text { provisions regarding the award of the public } \\
\text { procurement contract/framework agreement from Law } \\
\text { no. 98/2016; }\end{array}$ \\
\hline E.14 & $\begin{array}{l}\text { Sub-process for the legalization of notices issued for } \\
\text { the transcription of certificates/extracts of birth, } \\
\text { marriage, death issued by foreign authorities, as well } \\
\text { as those for the rectification of civil status documents } \\
\text { and/or entries on them, as well as the report that is the } \\
\text { basis for issuing the assent in the case of registration of } \\
\text { the birth after 30 days; }\end{array}$ \\
\hline E.15 & $\begin{array}{l}\text { Sub-process for approving the report on the proposal to } \\
\text { admit or reject the application for a change of name by } \\
\text { administrative means; }\end{array}$ \\
\hline E.16 & $\begin{array}{l}\text { The subprocess of ensuring the protection of personal } \\
\text { data, as well as the security of the documents of the } \\
\text { compartment, under the legal provisions in force. }\end{array}$ \\
\hline
\end{tabular}

\section{F.0 Human Resources Management Process}

This process comprises some sub-processes, some of which are set out in Table 6:

Table 6. Sub-processes included in the Human Resources Management Process

\begin{tabular}{|c|l|}
\hline F.0 & \multicolumn{1}{|c|}{ Human Resources Management } \\
\hline F.1 & $\begin{array}{l}\text { The sub-process of keeping records of the salary or } \\
\text { income tax assimilated to the salary; }\end{array}$ \\
\hline F.2 & $\begin{array}{l}\text { Sub-process for calculating gross salaries, rest leave, } \\
\text { and sick leave of D.J.E.P. Sibiu; }\end{array}$ \\
\hline F.3 & $\begin{array}{l}\text { Sub-process for compiling half-yearly statistical } \\
\text { reports on staff structure and staff costs; }\end{array}$ \\
\hline F.4 & $\begin{array}{l}\text { The sub-process for drawing up and updating the } \\
\text { professional files of civil servants, at least once a year, } \\
\text { and whenever necessary, ensures the transmission of }\end{array}$ \\
\hline
\end{tabular}

\begin{tabular}{|c|c|}
\hline & $\begin{array}{l}\text { data to the National Agency of Civil Servants, ensures } \\
\text { the safekeeping of professional files, keeping the } \\
\text { confidentiality of the information to which it has } \\
\text { access, under the law; }\end{array}$ \\
\hline F. 5 & $\begin{array}{l}\text { The sub-process for drawing up the necessary } \\
\text { documentation regarding the appointment/hiring, } \\
\text { promotion, } \\
\text { modification/suspension/termination/termination of } \\
\text { the employment/employment relationship of civil } \\
\text { servants/contract staff within the D.J.E.P. Sibiu; }\end{array}$ \\
\hline F.6 & $\begin{array}{l}\text { The sub-process for establishing the necessary funds to } \\
\text { cover staff costs and aims to be included in the budget } \\
\text { of revenues and expenditures of the D.J.E.P. Sibiu; }\end{array}$ \\
\hline F.7 & $\begin{array}{l}\text { The sub-process for drawing up the retirement files for } \\
\text { age limit, disability, and survivor, as the case may be, } \\
\text { and submits them for settlement to the County Pension } \\
\text { House; }\end{array}$ \\
\hline F. 8 & $\begin{array}{l}\text { The sub-process for calculating and keeping up to date } \\
\text { the record of seniority is necessary for granting the rest } \\
\text { leave and the corresponding grading and transmits to } \\
\text { those interested the data necessary for the granting of } \\
\text { these rights; }\end{array}$ \\
\hline F.9 & $\begin{array}{l}\text { Sub-process for keeping records of service and control } \\
\text { cards issued to D.J.E.P. Sibiu; }\end{array}$ \\
\hline F. 10 & $\begin{array}{l}\text { Sub-process of updating, drawing up, and keeping } \\
\text { records of documents in the professional files of civil } \\
\text { servants and contract staff; }\end{array}$ \\
\hline F.11 & $\begin{array}{l}\text { Sub-process for keeping track of the number of days of } \\
\text { temporary incapacity for work for employees; }\end{array}$ \\
\hline F.12 & $\begin{array}{l}\text { The sub-process for drawing up and submitting for } \\
\text { approval the program for carrying out rest leave and } \\
\text { following its development; }\end{array}$ \\
\hline F.13 & $\begin{array}{l}\text { The subprocess of drawing up and issuing certificates } \\
\text { regarding the seniority in work/specialty of the } \\
\text { graduated studies, regarding the number of days of } \\
\text { incapacity for work, as well as other certificates } \\
\text { requested by the D.J.E.P. Sibiu; }\end{array}$ \\
\hline F.14 & $\begin{array}{l}\text { The sub-process of keeping and operating the register } \\
\text { of the staff of the institution; }\end{array}$ \\
\hline F.15 & $\begin{array}{l}\text { Sub-process for ensuring the protection of personal } \\
\text { data, as well as the security of the documents of the } \\
\text { compartment, under the legal provisions in force; }\end{array}$ \\
\hline
\end{tabular}

\section{G.0 The Public Relations Process}

This process comprises some sub-processes, some of which are set out in Table 7:

Table 7. Sub-processes included in the Public Relations Process

\begin{tabular}{|l|l|l|l}
\hline G.0 & Public Relations Process \\
\hline
\end{tabular}


G.1 The sub-process of analysis, preparation, and assurance of the transmission of the answer to the petitions addressed to D.J.E.P. Sibiu, in case the petitions were assigned to this department, collaborating with the other departments within the institution, under the provisions of O.G. no. 27/2002 regarding the regulation of the activity of solving the petitions and with the provisions of the present Regulation;

G.2 Sub-process of centralization, processing/analysis of information published in the media regarding the activity of D.J.E.P. Sibiu and broadcasts, with the agreement of the management of the institution, in conditions of transparency and compliance with the legal provisions, press releases;

G.3 The subprocess of contributing, in collaboration with the structures within the institution and with its management, to the fluidization of the exchange of information between D.J.E.P. Sibiu, local community public services for the registration of persons, town halls in the county (delegated civil status officers) and citizens;

G.4 The sub-process of collaboration with the management of the institution and with the structures within it for obtaining information of public interest, which should be mediated through the media, in conditions of administrative transparency; drafts and ensures the transmission of press releases and information to news agencies, newspapers, magazines, television, radio, fax or e-mail;

G.5 The subprocess of organizing press conferences, at the request of the leadership of the D.J.E.P. Sibiu, so that it can be reflected, through a transparent, uncensored, and honest dialogue, the activity submitted in the service of the citizens;

G.6 Sub-process of participation in setting up and updating information on the D.J.E.P. Sibiu, together with the Informatics Department;

G.7 The sub-process of organizing and carrying out the activities of informing the public about the activity of the D.J.E.P. Sibiu;

G.8 The sub-process of making available to the public the information of public interest that is disseminated ex officio or upon request, according to Law no. 544/2001 on free access to information of public interest, amended and supplemented, in collaboration with the specialized structures within the institution;

G.9 The sub-process for organizing the public hearing activity provided by the D.J.E.P. Sibiu.

\section{H.0 Information Systems Management Process}

This process comprises some sub-processes, some of which are set out in Table 8:
Table 8. Sub-processes included in the Information Systems Management Process

\begin{tabular}{|c|c|}
\hline H.0 & Information Systems Management Process \\
\hline H.1 & $\begin{array}{l}\text { Sub-process of computerization and computerized } \\
\text { management of all activities suitable for computer } \\
\text { processing that belong to the D.J.E.P. Sibiu; }\end{array}$ \\
\hline H.2 & $\begin{array}{l}\text { The sub-process of responsibility for the proper } \\
\text { functioning of the system, manages and supervises the } \\
\text { material resources involved: hardware, software, and } \\
\text { communications; }\end{array}$ \\
\hline H.3 & $\begin{array}{l}\text { The sub-process of proposing the necessary hardware } \\
\text { and software equipment as well as providing assistance } \\
\text { in their distribution; }\end{array}$ \\
\hline H.4 & $\begin{array}{l}\text { The sub-process of elaborating, together with the users, } \\
\text { the list of applications and the priorities in their } \\
\text { realization at the level of D.J.E.P. Sibiu, proposing } \\
\text { internal procedures (practical guides) for optimizing } \\
\text { data flow, ensuring their protection and access to } \\
\text { optimizing information; }\end{array}$ \\
\hline H.5 & $\begin{array}{l}\text { Subprocess for providing support and assistance in the } \\
\text { implementation of purchased programs; }\end{array}$ \\
\hline H.6 & $\begin{array}{l}\text { Sub-process for providing assistance, advice, and } \\
\text { training to specialized personnel or, where appropriate, } \\
\text { proposing training courses in specialized institutions } \\
\text { on computer operation, how to use installed programs } \\
\text { and maintenance of computer equipment calculation; }\end{array}$ \\
\hline H.7 & $\begin{array}{l}\text { Responsibility for the implementation of information } \\
\text { and communication system security policies; }\end{array}$ \\
\hline H.8 & $\begin{array}{l}\text { The sub-process of responsibility, to maintain and } \\
\text { update the site of the institution, based on the } \\
\text { information received from the specialized structures } \\
\text { within it, approved in advance by the executive } \\
\text { director of the D.J.E.P. Sibiu, displays, on the website } \\
\text { of D.J.E.P. Sibiu, information of public interest; }\end{array}$ \\
\hline H.9 & $\begin{array}{l}\text { The sub-process of ensuring, through the staff of the } \\
\text { Litigation, Human Resources, and Public Relations } \\
\text { Department, the access of the mass media to } \\
\text { information of public interest; }\end{array}$ \\
\hline H.10 & $\begin{array}{l}\text { Sub-process for ensuring the functionality of computer } \\
\text { networks and connection and communication } \\
\text { equipment, network access, monitoring, and } \\
\text { maintenance; }\end{array}$ \\
\hline H.11 & Sub-process for managing and using e-mail accounts; \\
\hline H.12 & $\begin{array}{l}\text { Sub-process for managing and using e-mail accounts } \\
\text { between D.J.E.P. Sibiu and the institutions/authorities } \\
\text { of the public administration of Sibiu county; }\end{array}$ \\
\hline H.13 & $\begin{array}{l}\text { The subprocess of ensuring the protection of personal } \\
\text { data, as well as the security of the documents of the } \\
\text { compartment, under the legal provisions in force; }\end{array}$ \\
\hline
\end{tabular}


H.14 Sub-process for drawing up and participating in the training and education program for local Community public service personnel, updating databases, ensuring access to and compliance with the rules on the protection of personal data and security documents, under the legal provisions in force and, last but not least, the operation and maintenance of the computer equipment and the use of the programs.

\section{I.0 The Process Financial-Accounting}

This process comprises some sub-processes, some of which are set out in Table 9:

Table 9. Sub-processes included in the Process FinancialAccounting

\begin{tabular}{|c|c|}
\hline I.0 & Process Financial-Accounting \\
\hline I.1 & $\begin{array}{l}\text { The sub-process of ensuring the correct and timely } \\
\text { execution of accounting records on fixed and current } \\
\text { assets, cash, own funds and other funds, debtors, } \\
\text { creditors, and other settlements, investments, budget } \\
\text { expenditures, and revenues; }\end{array}$ \\
\hline I. 2 & $\begin{array}{l}\text { The sub-process of ensuring, drawing up, circulating, } \\
\text { and keeping the supporting documents underlying the } \\
\text { accounting records; }\end{array}$ \\
\hline $\mathrm{I} .3$ & $\begin{array}{l}\text { The sub-process for carrying out all operations related } \\
\text { to deductions from salaries and draws up the documents } \\
\text { for performing the control of salaries at the Treasury; }\end{array}$ \\
\hline I.4 & $\begin{array}{l}\text { Sub-process for keeping records of approved revenues } \\
\text { and expenditures according to budget classification; }\end{array}$ \\
\hline I.5 & $\begin{array}{l}\text { The sub-process of carrying out the accounting records } \\
\text { and ensuring the settlement of the expenses financed } \\
\text { from special-purpose funds established according to the } \\
\text { law; }\end{array}$ \\
\hline I.6 & $\begin{array}{l}\text { Monthly sub-process of preparation and transmission, } \\
\text { to the General Directorate of Public Finance Sibiu, the } \\
\text { statement on "Payment obligations to the consolidated } \\
\text { general budget"; }\end{array}$ \\
\hline I.7 & $\begin{array}{l}\text { Sub-process for making payments and receipts, in cash, } \\
\text { based on supporting documents; }\end{array}$ \\
\hline I.8 & $\begin{array}{l}\text { The sub-process of exercising the daily control over the } \\
\text { operations performed through the cashier of the unit; }\end{array}$ \\
\hline I.9 & $\begin{array}{l}\text { The sub-process of ensuring the capitalization of the } \\
\text { annual inventory of the patrimony D.J.E.P. Sibiu, } \\
\text { determines the results of the inventory and their } \\
\text { registration in accounting; }\end{array}$ \\
\hline I. 10 & $\begin{array}{l}\text { Sub-process to ensure strict compliance with the legal } \\
\text { provisions on the integrity of the tangible property and } \\
\text { take all legal measures to recover damages; }\end{array}$ \\
\hline I.11 & $\begin{array}{l}\text { The monthly checking balance sub-process for the } \\
\text { synthetic and analytical accounts and monitors the } \\
\text { concordance between them; }\end{array}$ \\
\hline
\end{tabular}

I.12 Quarterly and annual sub-process for drawing up the balance sheet and its explanatory report;

I.13 Subprocess for ensuring the automatic processing of data according to the technical operating documents;

I.14 Sub-process for performing calculations based on economic and financial indicators on revenue and expenditure based on which it draws up the draft annual budget, broken down by quarter;

I.15 The subprocess of taking the necessary measures, together with the other structures, as D.J.E.P. Sibiu to carry out its activity so that the expenses do not exceed the provisions of the budget;

I.16 Sub-process for organizing, keeping track of, and reporting on employment, liquidation, ordering, and payment of expenditure according to budget classification;

I.17 The subprocess of drawing up monthly, respectively quarterly, the opening of budgetary credits, respecting the compliance with the legal provisions, and transmits them to the Sibiu County Council, respectively to the Sibiu Public Finance Administration;

I.18 The sub-process for drawing up the requests and substantiation notes regarding the transfers of appropriations for the own budget and budgetary rectifications, according to the regulations in force, which they submit to the Sibiu County Council;

I.19 Sub-process for formulating proposals for changes in budget allocations through adjustments and transfers of appropriations;

I.20 Sub-process for ensuring the protection of personal data, as well as the security of the documents of the compartment, under the legal provisions in force

\section{J.0 Technical-Material Assurance Process}

This process comprises some sub-processes, some of which are set out in Table 10:

Table 10. Sub-processes included in the Process FinancialAccounting

\begin{tabular}{|l|l|}
\hline J.0 & \multicolumn{1}{|c|}{ Technical-Material Assurance Process } \\
\hline J.1 & $\begin{array}{l}\text { The sub-process of ensuring the proper management of } \\
\text { the assets or values at its disposal, assuming legal } \\
\text { responsibility for the damages it causes to the institution; }\end{array}$ \\
\hline J.2 & $\begin{array}{l}\text { The sub-process of monitoring and responsibility for the } \\
\text { proper execution of maintenance works, rational and } \\
\text { efficient use of the related installations, of the other fixed } \\
\text { assets and inventory objects in the patrimony of the } \\
\text { D.J.E.P. Sibiu; }\end{array}$ \\
\hline J.3 & $\begin{array}{l}\text { The sub-process for carrying out the periodic inventory } \\
\text { of the existing goods in the warehouse, as well as the } \\
\text { annual inventory of the patrimony of the D.J.E.P. Sibiu, }\end{array}$ \\
\hline
\end{tabular}




\begin{tabular}{|l|l|}
\hline & $\begin{array}{l}\text { proposes measures for scrapping, downgrading, or } \\
\text { removing the inventory goods and ensures the } \\
\text { fulfillment of the provisions issued in this regard, } \\
\text { drawing up the necessary documents; }\end{array}$ \\
\hline J.4 & $\begin{array}{l}\text { Sub-process of concern for concluding contracts for } \\
\text { utilities, procurement of goods, provision of services } \\
\text { and/or works, under the provisions of Law no. 98/2016 } \\
\text { on public procurement and Government Decision no. } \\
\text { 395/2016 for the approval of the Methodological Norms } \\
\text { for the application of the provisions regarding the award } \\
\text { of the public procurement contract/framework } \\
\text { agreement from Law no. 98/2016, within the limits of its } \\
\text { competence, and aims at carrying out the contracts } \\
\text { concluded with the economic operators; }\end{array}$ \\
\hline J.5 & $\begin{array}{l}\text { Sub-process of analysis and making proposals to the } \\
\text { Executive Director of D.J.E.P. Sibiu regarding the } \\
\text { program of investments, endowments, and repairs to the } \\
\text { installations and other fixed assets under the } \\
\text { administration of D.J.E.P. Sibiu, follow the } \\
\text { accomplishment of the respective works and participates } \\
\text { in the accomplishment of the receptions; }\end{array}$ \\
\hline J.6 & $\begin{array}{l}\text { Sub-process for ensuring and verifying the application of } \\
\text { fire protection rules, as well as labor protection and } \\
\text { safety rules; }\end{array}$ \\
\hline J.7 & $\begin{array}{l}\text { Sub-process for ensuring the protection of personal data, } \\
\text { as well as the security of the documents of the } \\
\text { compartment, under the legal provisions in force. }\end{array}$ \\
\hline
\end{tabular}

\section{K.0 The Registry Process}

This process comprises some sub-processes, some of which are set out in Table 11:

Table 11. Sub-processes included in the Registry Process

\begin{tabular}{|l|l|}
\hline K.0 & \multicolumn{1}{|c|}{ Registry Process } \\
\hline K.1 & $\begin{array}{l}\text { Sub-process of receiving and recording correspondence } \\
\text { in writing or by e-mail/mail / FTP and distributing it, } \\
\text { based on the signature, to the structures within the } \\
\text { institution, according to the resolution of the executive } \\
\text { director of D.J.E.P. Sibiu, also ensuring its shipment; }\end{array}$ \\
\hline K.2 & $\begin{array}{l}\text { The follow-up sub-process, in the general registry of the } \\
\text { institution, the communication within the legal term of } \\
\text { the answers to the requests addressed directly or } \\
\text { indirectly to the executive director of the D.J.E.P. Sibiu } \\
\text { and informs the management of D.J.E.P. Sibiu } \\
\text { regarding the observance / non-observance of these } \\
\text { terms; }\end{array}$ \\
\hline K.3 & $\begin{array}{l}\text { The sub-process of ensuring and following the } \\
\text { download based on the daily schedule of the } \\
\text { correspondence resulting from the activity of the } \\
\text { institution, being responsible for its centralization; }\end{array}$ \\
\hline K.4 & $\begin{array}{l}\text { The insurance sub-process, together with the other } \\
\text { structures of the D.J.E.P. Sibiu, of the implementation } \\
\text { of Law no. 52/2003 on decision-making transparency in } \\
\text { public administration; }\end{array}$ \\
\hline
\end{tabular}

K.5 Sub-process for transmitting electronic correspondence to public administration institutions/authorities of Sibiu County;

K.6 Sub-process for ensuring the protection of personal data, as well as the security of the documents of the compartment, under the legal provisions in force.

\section{OWN ANALYSIS OF PROCESS CATEGORIES AND PROPOSAL OF A PROCESS MAP}

The public organization, Sibiu County Directorate for the Registration of Persons, has a hierarchical organizational form, with well-defined responsibilities at the level of each structure divided into services and compartments. The activities of the organization are regularly analyzed, and new opportunities are sought to improve the quality of services. These improvements can be found in the rules of organization and operation, which are reviewed annually or as often as necessary.

Currently, the quality management system within the studied organization does not take a process-based approach. Our proposal for a process-based approach respects the principles of quality management presented in ISO 9000: 2015 and ISO 9004: 2018. The process-based approach has the advantage of controlling the connection between individual processes as well as control and interaction between processes.

The processes that we have identified within the Sibiu County Directorate for the Registration of Persons are based on the organization and functioning regulation in which the activities corresponding to the services and compartments within the organization are pointed out.

Within the studied organization there are and interact three types of processes:

- Management processes;

- Central processes;

- Basic processes or support processes.

Management processes are institutional, strategic processes that coordinate the development of central processes and basic processes. These processes involve actions on setting the goals of the organization, setting responsibilities; establishing the possibilities and means of communication, identifying the need for human and material resources, infrastructure and the working environment, processes related to the evaluation, analysis, and improvement of results.

The management processes were divided into:

- General administration processes;

- Executive administration processes;

- Civil status administration processes by the head of the civil status service;

- Processes of administration of the service of personal records by the head of the service of personal records.

The central processes are the processes of direct realization of the services following some requirements of the citizens and of the institutions with which they collaborate. Central processes create value and determine the quality of services. The central processes were divided into:

- Control coordination processes within the civil status process; 
- Operational processes entries in the civil status register within the civil status process;

- Processes records of persons within the general process registration of person.

The basic or support processes are the processes that, through punctual, discontinuous, and limited interventions, support the main processes and the managerial processes, ensuring their normal and efficient functioning. Support processes are professional activities that serve the core business. The support processes were divided into:

- Contentious-Legal processes;

- Human resources management processes;

- Public relations processes;

- Information systems management processes;

- Financial processes - accounting;

- Technical material insurance processes;

- Registry processes.

After identifying and classifying the processes, we make a map of the processes. The process map gives, in a visual way, a presentation of the existing processes in the organization. The process map shows the process flows that influence the quality.

This tool allows the development of a common vision and understanding of the dynamics of the processes and their correlations in a global way within the studied organization. In this way, we can highlight ways to improve within a process and identify the constraints to which it is subject. A process map is used when changes occur in the company and when you want to explain how the organization works.

We made the map of the processes starting from the basic processes, then the central ones up to the management processes realizing the connections that appear between them. A representation of the process map is shown in Figure 1.

The process-based approach:

- Allows to focus on the integration, alignment, and effective connection of the processes with the planned objectives and targets;

- It also allows the organization to focus on improving the effectiveness and efficiency of processes;

- Facilitates performance which, in turn, provides the customer with confidence in the organization's ability to deliver quality;

- Promotes a transparent and constant flow of operations within the organization;
- Contributes to reducing costs and shortening operational cycles through the efficient use of resources;

- Allows interest in improving process outcomes and generating consistently and predictably improved outcomes;

- Facilitates involvement, clear definition of employee responsibilities and authorities.

\section{CONCLUSION}

In this paper, for the beginning, I made a presentation of the organization in which I carry out my activity, showing the place and the role of the organization Sibiu County Directorate for the Evidence of Persons. Then we tried to expose the mode is organized the activities that take place in the organization.

As in the private sector, in public organizations, reducing spending, increasing the quality of services to citizens, improving and streamlining the management system are becoming a priority. The process-based approach can become a solution to these requirements.

The process-based approach can be applied in any organization, private and public. Also, can be used in any management system regardless of its type, size, or complexity.

The process-based approach is a comprehensive concept, including identifying and planning processes and their interactions. The process-based approach is one of the principles of quality management based on the requirements of the ISO 9001: 2015 standard. To increase quality, the application of the ISO 9000: 2015 standardized can be an essential tool. Starting from this desideratum, in this paper, following the documentation and collaboration with the management and colleagues from the organization subject to research, we managed, as a personal contribution, to identify and describe the existing processes. I mention that at the moment, within the studied organization, there is no process-oriented approach.

By performing process analysis, we drew up a map of the existing processes, with the current situation within the organization.

Making the process map, visually illustrates the existing processes in the organization. The process map shows the process flows.

As a follow-up, we will continue to make a new process map following processes analysis and propose process improvements to increase the quality and efficiency of services. Subsequently, we intend to model the processes with a method that we will establish later. 


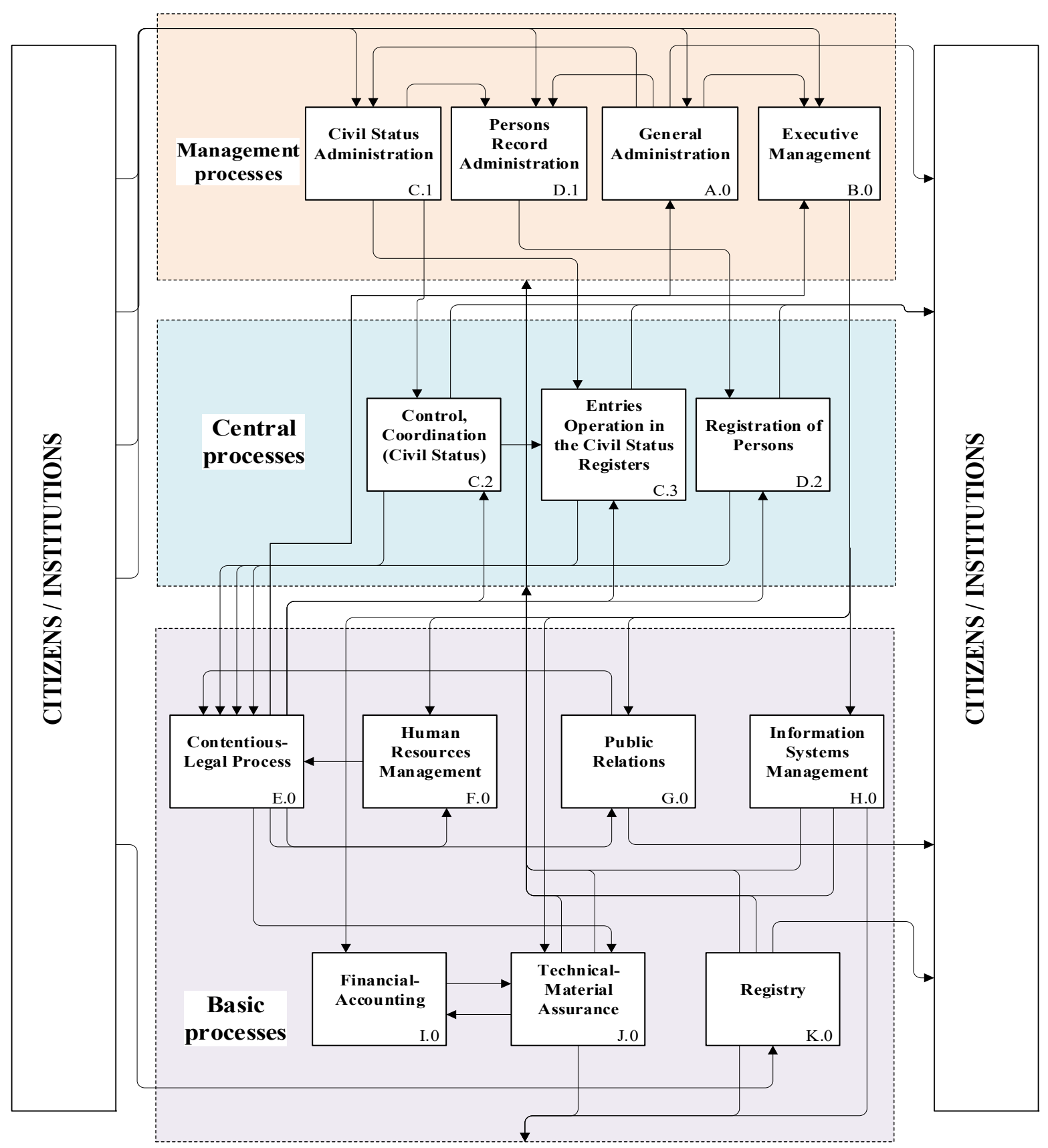

Figure 1. The process map within the D.J.E.P. Sibiu

\section{REFERENCES}

1. D.E.P.A.B.D. (2018). O retrospectivă a evidenței persoanelor în România. București.

2. D.E.P.A.B.D. (2019). Identitatea românilor în spațiul multinațional european. București.

3. Lee, R., \& Dale, B. G. (1998). Business Process Management: a review and evaluation. Business Process Management Journal Vol. 4 No. 3, 214-225.

4. Oprean, C., Țîtu, M., \& Bucur, V. (2011). Managementul global al organizației bazată pe cunoștințe. București: Editura AGIR, ISBN 978-973-720-363-2.

5. Simion, H. A., Thompson, V. A., \& Smithburg, D. (2003). Administratia publica. Bucuresti: Editura Cartier.

6. Tricker, R., \& Bruce, S. L. (2001). ISO 9001:2000 in brief. Oxford: Butterworth-Heinemann
7. D.J.E.P. Sibiu - Regulament de organizare şi funcţionare al Direcţiei Judeţene de Evidenţă a Persoanelor Sibiu. (2021, Noiembrie 25). Preluat de pe: http://www.djepsibiu.ro/wpcontent/uploads/2020/03/ROF-03.12.2019.pdf

8. http://www.djepsibiu.ro

9. Legea 215, A. 3. (2001). Monitorul Oficial nr. 204/23 apr. 2001.

10. OUG 82, d. 2. (12 decembrie 2012). Monitorul Oficial nr. 838. Monitorul Oficial nr. 838

11. OG. nr. $84 / 2001$

12. Legea nr. $372 / 2002$

13. H.G. nr. $9 / 2005$

14. H.G. nr. 2104/2004

15. H.G. nr. $1367 / 20$ 